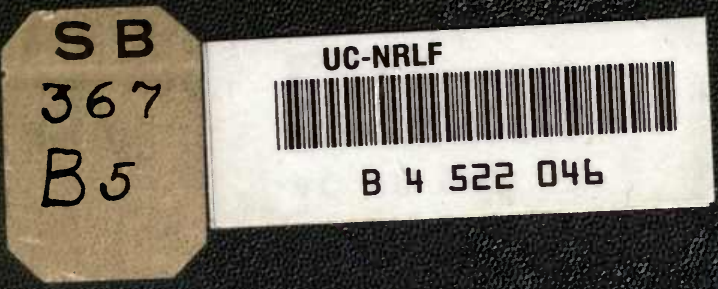





\section{THE OLIVE TREE}

axp ris

PRODUCTS,

AND THE

\section{Suitability of the Soil and Climate of California}

FOR ITS

Extensive and Profitable Cultivation

BY

John I. Bleasdale, D. D., F. G. S.

Secretary of the Board of State Viticultural Commissioners.

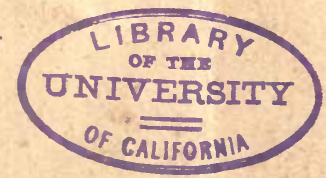

DEWEY \& CO., PUBIISIIERS,

San francisco, cal 



\section{THE OLIVE TREE}

AND ITS

\section{PRODUCTS,}

AND THE

\section{Suitability of the Soil and Climate of California}

FOR ITS

Extensive and Profitable Cultivation.

\section{ĐY}

John I. Bleasdale, D. D., F. G. S.

Secretary of the Board of State Viticultural Commissioners.

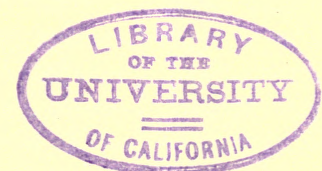


To Prof. E. W. Hilliard, Professor of Agriculture in the State University:

DEAR SIR :-I do myself the honor of inscribing the following little treatise, on "The Olive Tree and its Products," and "The Suitability of the Climate of California for its Extensive Cultivation," to you, as an expression of my admiration of your efforts to benefit this State by introducing and fostering the profitable secondary industries of Southern Europe.

75690

JOHN I. BLEASDALE. 


\section{THE OLIVE TREE.

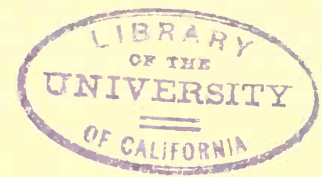

Among the vegetable substances which minister to the daily wants of man throughout Southern Europe, Egypt, and sub-tropical Asia, the olive and its products hold the next place after cereals and vines in economic and commercial importance. So remunerative has the culture of the olive been considered, that, even in portions of a country where it does not form the principal aim of the cultivator, it is deemed his most valuable secondary or subsidiary resource. Where the land is suited for wheat, especially on low hill-sides, the olive trees are planted at considerable distances asunder all through it, and need no care beyond that bestowed on cultivating the ground for ordinary crops. The cereals may perish by blight or fire, but the olive crop is certain. Land in Southern Europe, with soil and climate very nearly the same as those of California, when cut up into very small holdings, still supports dense populations in reasonable comfort. The people are frugal, industrious, thrifty, and yet enjoy life with a keenness but little felt in the hurry and bustle of activity in new countries like California or Australia.

Lands of every quality, suitable for every variety of sub-tropical produce, are abundant in California-so abundant and cheap that the cultivation is generally slovenly, and nearly always cropped with the same cereals, or roots, till it gradually becomes exhausted, and a prey to mere weeds. Like many other things which are plentiful and cheap, little respect is paid to land beyond its present use. Not so, however, in countries like Belgium and Lombardy, Italy. There every inch is turned to account, and kept in uniform fertility from generation to generation through thousands of years. No people better understand and practice irrigation than the Lombards; and there is many a useful hint to be gathered out of their experience which would amply repay the Californian cultivator, if he only knew it. Now that attention is being turned to the establishment of rural colonies, with a view to special industries, such as small vineyards, the making of raisins, drying of fruit, and the like, these remarks, and others thrown out as occasion may offer in these pages, have a pregnant meaning for those who are entertaining the notion of settling on country lands, or have already so settled. In fact, it is chiefly for them that I write. In certain

highly favored localities, such as the districts about Fresno, the system of agricultural colonies has been tried, where the holdings are small, say from twenty to perhaps one hundred acres, and the result so far is encouraging. Still, the land is as yet not reduced to its full bearing capacity, whether as to vineyards, grain crops, root crops, such as the sweet potato, or hay, which form the staple industries at the present time.

\section{OTHER SUITABLE INDUSTRIES.}

On a thirty or forty-acre farm the eye of a Belgian or of a Lombard would at a glance perceive where the support of the family might be obtained, with little or no additional outlay or labor than such as could be done by children in odd hours. Bees are frequently kept, it is true; but where do we find the natural accompaniment of them?-aromatic plants, such as rosemary, lavender, lemon, thyme, etc. - the money value of which for their essential oils would be considerable. Fig trees are beginning to be thought about for their fruit, but as yet we nowhere see them planted out in vineyards, as they should be-here and there, especially in the lowest and dampest parts, because there they serve the excellent purpose of attracting small birds and flies which would otherwise play havoc among the grapes. The shade is grateful, and the fruit, ripening as it does weeks before the grapes, effectually gathers those mischievous pests to itself alone, for they prefer the ripe fig to all other fruit.

Nearly every expense attending on housekeeping is got out of these secondary industries. Nay, more; in the vicinity of Lisbon, in former years the crop of olives grown in the wheat field paid probably more than the whole expense of cultivating the land and securing the harvest. Of course, these secondary industries vary in different localities, and not unfrequently in the same district. Some situations have acquired a reputation for the excellence of their figs; others for their walnuts, chestnuts, or hazel nuts; others again for the abundance and excellence of herbs, such as saffron, pimento, mint, licorice, etc.-all of which have a certain market value. By-products, such as those enumerated, together with eggs and chickens, which they raise in quantity 
for sale, and perhaps a goat or two for milking, keep the family in what among them is considered quite reasonable comfort and respectability. Again, in the sub-Apennine Mountains the chestnut is the principal stand-by. So important is the chestnut as an article of food and nourishment, that even should a mother lose her milk, or has had but little or none, she has only to have recourse to her store of chestnut meal, however tender her babe may be, when a spoonful of it made into pap and strengthened with a small quantity of wine will answer all the ends required, as many a sturdy Italian now living in California can testify.

In places in Southern Europe, where every bit of land is turned to account, it not unfrequently happens that there is a steep, rocky corner where vines could not be profitably cul-

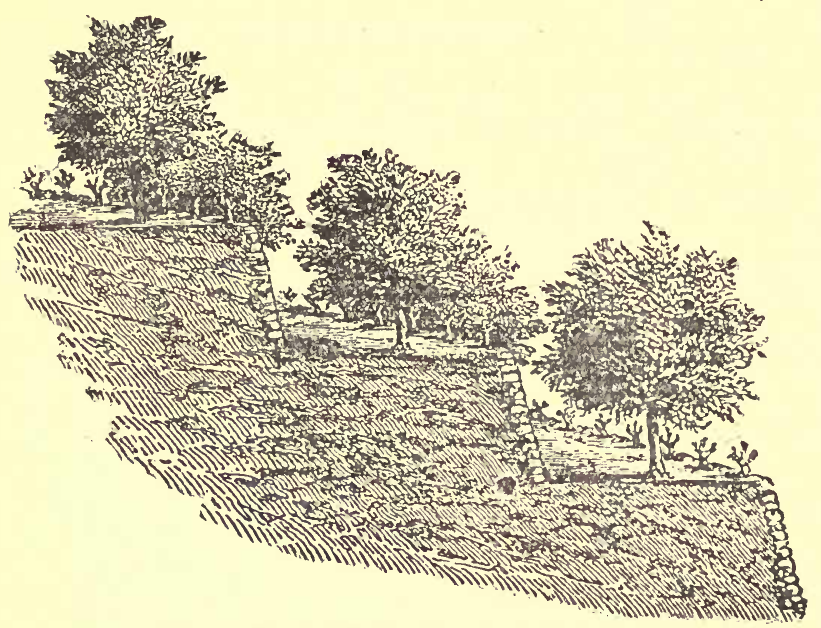

TERRACING VINES AND OLIVE TREES.

tivated, in which case rough terracing is had recourse to to keep the soil together, and allow some cultivation, as is shown in the engraving.

One might naturally ask why the olive tree has ever been such a favorite in Southern Europe, Asia, and Africa with men who have an eye to economic industries? It certainly is not a very ornamental tree. To reply briefly, I should say :

(r.) Because of the ease with which it can be raised from seed; or, better still, propagated from large cuttings.

(2.) The little attention the plant requires when once it has broken into leaf.

(3.) Because when properly planted, truncheon fashion, it will usually begin to bear the fourth year-not unfrequently a few berries the third year.

(4.) The certainty of a crop. It usually bears in alternate years a heavy and a light crop.

(5.) The fact that no great breadth of land is needed for a plantation since it can be readily grown along fences and hedge-rows, or otherwise worthless stony places.

(6.) Being an evergreen, when planted around fences it forms a capital shelter for more delicate fruits, vineyards, etc.

(7.) Last, but not least, because when once brought into bearing, it will not need to be renewed, but will be still yielding its annual crop when the last ounce of gold or silver shall have been wrung from the bowels of the earth.

\section{THE LONGEVITY OF THE OLIVE TREE}

Is wonderful. Its life-period is not certainly known. The tree above ground will, of course, die out. In fact, in the long course of years it becomes a mere shell, "for it begins to die at the core, but the root does not perish. Out of this springs the new tree. In the very old olive groves about Palma, near Lisbon, in Portugal, I have noted this circumstance oftener than once. Travelers most competent to judge are agreed that the present olive trees on Mount Olivet, near Jerusalem, are the same that Christ prayed under and his disciples fell asleep under nineteen hundred years ago, and they are even now yielding their annual crop of fruit.

\section{GROUND FOR A PLANTATION.}

When the purpose' is to form an olive grove to be devoted to the growth of the olive tree for fruit alone, then all experience points to a moderately strong soil such as would bear wheat, with a rather moist subsoil, as the best. Drainage will be found necessary where there is any danger of stagnant water lodging about the roots. These conditions have been found in the greatest perfection on low hills and slopes exposed more or less to sea breezes. From my own experience and observation deep trenching was not needed, but, of course, very advantageous when labor and cost are of little consideration. If the holes for the plants be dug three feet in diameter by about the same in depth, that will be sufficient to give them a good hold on the ground, and for the rest they will take care of themselves. In this connection, I gladly avail myself of remarks made by Mr. B. B. Redding, of San Francisco, in the course of an interesting paper on olive growing read two years ago before the Academy of Sciences:

"This tree will grow in almost any soil except that containing much moisture. Marsh states 
'that it prefers a light warm ground, but does not thrive in rich alluvial land, and grows well on hilly and rocky surfaces.' Bernays says 'that it thrives and is most prolific in dry calcareous schistose, sandy, and rocky situations. The land must be naturally or artificially well drained. Its great enemy is excess of moisture. It rejoices in the mechanical looseness of sandy, gravelly and stony soils, and in freedom from stagnant moisture.' Brande asserts that it only grows well and yields large crops 'in a warm and comparatively dry climate.' Dr. Robinson says 'it delights in a stony soil, and thrives even on the sides and tops of rocky hills where there is scarcely any earth; hence the expression in the Bible, "oil out of the flinty rock." " Hillhouse, in his article on this tree in Michaux's Sylva, says: 'The olive accommodates itself to almost any variety of soil, but it shuns a redundancy of moisture, and prefers loose calcareous fertile lands mingled with stones, such as the territory of Attica and the south of France. The quality of its fruit is essentially affected by that of the soil. It succeeds in good loam capable of bearing wheat, but in fat lands it yields oil of an inferior flavor, and becomes laden with a barren exuberance of leaves and branches. The temperature of the climate is a consideration of more importance than the nature of the soil.' Downing, in writing of this tree in Southern Europe, says: 'A few olive trees will serve for the support of an entire family who would starve on what could otherwise be raised on the sane surface of soil; and dry crevices of rocks and almost otherwise barren soils in the deserts, when planted with this tree, become flourishing and valuable places of habitation." "'

\section{CLIMATE OF THE OLIVE TREE.}

The olive tree, like most other sub-tropical trees, has a wide range within which it will thrive and be fruitful, though the fruit grown at either of the extreme points of the range will generally be of inferior quality. In the warmer parts of Northern Italy it thrives and produces freely. About Lago di Como and Lago Maggiore it seems to touch the outermost limit of warmth. There the fruit is not unusually gathered when the snow is lying six inches thick over the ground. No one would advise the planting of it in California under the conditions last mentioned.

I am again glad to be able to avail myself of the patient industry of $\mathrm{Mr}$. Redding, for it requires much perseverence and zeal to work out climatic details such as will be found in the subjoined table and its introductory remarks.
It is matter for regret that his interesting paper has not been thrown out in a less perishable form than publication in the columns of a newspaper.

"For the purpose of ascertaining where within this State the olive can be successfully cultivated, I have gathered from the tables of temperature of the Smithsonian Institution and the Chief Engineer's Department of the railroad companies, a list of all the places whose temperatures fall within those limits which Humboldt states have been found to be essential. The regions which this list represents could, without doubt, be extended, had more attention been given in different parts of the State to observing and recording the variations in temperature. It will be remembered that the requisites of successful and profitable cultition are, that for the year it must be as warm as $57.17^{\circ}$. The mean for the coldest month must be as warm as $4 \mathrm{I} .5^{\circ}$, and at no time must the temperature fall below $14^{\circ}$. I cannot find in any authority how high a temperature it will bear, but as it is successfully grown in Algeria and Egypt, it could hardly be injured by the highest temperatures that occur at the places mentioned in the following list:

\begin{tabular}{|c|c|c|c|c|}
\hline Places. & 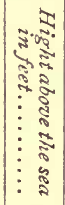 & 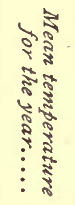 & 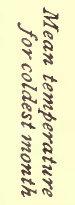 & $\begin{array}{l}\text { Lowest temperature } \\
\text { shown by thermom- } \\
\text { eter in any year. }\end{array}$ \\
\hline 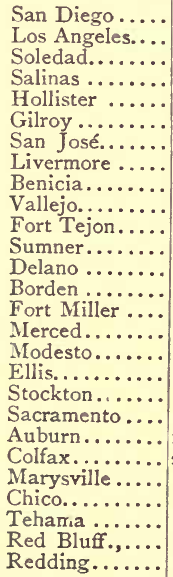 & $\begin{array}{r}150 \\
457 \\
182 \\
44 \\
284 \\
193 \\
86 \\
485 \\
64 \\
0 \\
3240 \\
415 \\
313 \\
274 \\
402 \\
171 \\
91 \\
76 \\
23 \\
30 \\
1363 \\
2421 \\
67 \\
193 \\
222 \\
307 \\
558\end{array}$ & $\begin{array}{l}62.49 \\
67.69 \\
59.08 \\
57.95 \\
61.46 \\
59.07 \\
59.60 \\
61.49 \\
58.77 \\
58.77 \\
58.03 \\
68.29 \\
68.64 \\
66.37 \\
66.56 \\
63 \cdot 16 \\
63.68 \\
63.00 \\
61.99 \\
60.48 \\
60.71 \\
60.05 \\
63.62 \\
62.46 \\
65.20 \\
66.22 \\
64 \cdot 14\end{array}$ & $\begin{array}{l}53.30 \\
58.95 \\
45.23 \\
48.25 \\
46.53 \\
44.45 \\
46.58 \\
49.52 \\
47.43 \\
47.41 \\
42.05 \\
46.71 \\
52.46 \\
45.44 \\
47.47 \\
48.14 \\
47.69 \\
46.46 \\
47.43 \\
46.21 \\
45.88 \\
45.49 \\
48.70 \\
45.19 \\
47.01 \\
48.29 \\
46.72\end{array}$ & 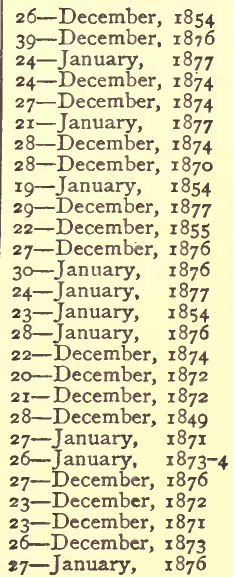 \\
\hline
\end{tabular}

"For the purpose of comparing the temperatures of the above named places in California with those of regions in which the produce of the olive is among the articles of the first agricultural and commercial importance, I have compiled from Blodgett's Climatology the mean annual and the mean winter temperatures, as 
also the mean temperature of the coldest month of the following prominent places in Italy, Spain, Portugal, France, Egypt, and Palestine:

\begin{tabular}{|c|c|c|c|}
\hline Places. & 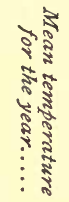 & 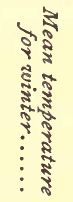 & 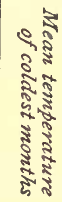 \\
\hline 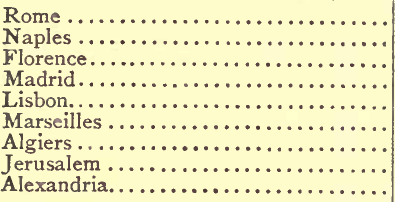 & $\begin{array}{l}60.05 \\
60.03 \\
59.02 \\
58.03 \\
61.04 \\
58.03 \\
64.03 \\
62.06 \\
66.08\end{array}$ & $\begin{array}{l}46.07 \\
49.6 \\
43.08 \\
45.02 \\
52.05 \\
45.02 \\
51.02 \\
49.06 \\
58.05\end{array}$ & $\begin{array}{l}45.00 \\
47.04 \\
41.02 \\
43.02 \\
51.04 \\
43.02 \\
53.02 \\
47.04 \\
57.03\end{array}$ \\
\hline
\end{tabular}

"A comparison of the above tables will show that so far as they relate to the mean for the year and the mean for the coldest month, the climate of Rome and Sacramento is nearly the same. So is Alexandria and Los Angeles; Florence and Fort Tejon; Lisbon and Livermore; Marseilles and Benicia; Algiers and San Diego, and Jerusalem and Merced. In but one case for the year is there a difference of more than one degree, and in but one case more than three degrees for the difference of the coldest month.

\section{THE WARM BELT OF THE FOOT-HILLS.}

"Another fact worthy of notice which has been suspected, but for the proof of which the data has not before been attainable, is that the zone in the Sierra, known as the foot-hills, is as warm for the year, and as warm for the coldest month, as the Sacramento Valley in the same latitudes. This warm belt certainly extends to an elevation of 2,500 feet, Colfax, with an elevation of 2,42I feet, has a mean for the year of $60.5^{\circ}$, and a mean for the coldest month of $45.49^{\circ}$ : while for the same periods Sacramento has for the year $60.48^{\circ}$, and for the coldest month $46.2 \mathrm{I}^{\circ}$. Fort Tejon, on the Tehachepi Mountains, elevation 6,240 feet, for the year, is but six degrees colder than Tulare, in the center of the valley, 3,000 feet below; while the temperature for the winter months is nearly the same, Fort Tejon having $42.5^{\circ}$, and Tulare $42.7^{\circ}$. This zone of warm temperature explains the success in the growth of oranges and other semi-tropical fruits, wherever planted below an elevation of 2,000 feet in the foot-hills of the Sierra. There have been omitted from the list of stations in California, San Francisco, Monterey, Pajaro, San Mateo, Petaluma, Visalia, and Tulare, for the reason that in the mean annuál temperature, or in the mean for the coldest months, they fall below $57^{\circ}$ or $4 \mathrm{I}^{\circ}$. Without doubt the olive could be grown in these places, but its cultivation could hardly be made profitable." There is a very generally received opinion that sea air is peculiarly favorable to the olive tree, and I respectfully indorse it from the observations I have been able to make. I know it flourishes, and is very prolific, far beyond the ordinary range of sea air, as in Egypt, Arabia, and Persia; but there seems to be a confusion of terms here. No one surely denies the fact of its growth, but disputes the goodness of its produce for human food. Did any one ever meet such an advertisement as this in the shop windows, or newspaper columns? The following appeared not very long ago as an advertisement:

\section{"SOMETHING NEW AND DELICIOUS.}

"Messrs. Brown \& Co., importers of groceries, oilmen's stores, etc., etc., have just received from Suez a consignment of olive oil from Central Egypt of most superior quality for salads, for cooking fish, etc. This oil has the merit of having been grown in a region remote from sea air, and consequently has never been under salime influence. Far superior to the Lucca article !" *

Vast quantities of olive oil are imported into England from those eastern countries, well enough suited for use in the manufacture of broadcloth. It is used mainly for that purpose, and is as useful as the best, and procurable at a low figure-say sixty cents per gallon. But the fine table oils of Southern Europe are very dear in comparison - from $\$ 1.25$ to $\$ 2$ per gallon. The contention is that sea-air, from whatever cause, has been found most beneficial in producing the finest fruit and oil. I shall have to remind the reader again of these remarks when I come to deal with the method of olive planting. Still it may be as well to say in this connection once for all that very nearly, if not quite, all the writers on olive trees and their oil refer only to the best kinds for human food, and the methods of their cultivation. But it must be kept in view that the consumption of olive oil in the form of food is only a fraction of the whole; and in countries where butter is excellent, plentiful, and cheap, oil will never become more than a condiment-so to speak-or a relish. The real consumers of olive oil are the woolen mills. When the yolk has been taken out of the wool, it must be soaked in olive oil for all finer kinds of cloths, and this oil need not be better than the worst yield of the berry. In this country such would be yielded by the second pressing, or third, and abundantly by

* The man who wrote the above was either an ignoramus or a cheat. 
trees planted in the fences, or on waste bits of land, or for shelter in vineyards and orchards, and here and there on cultivated lands, etc. This is the oil which in Europe brings less than a dollar per gallon, yet here worth more than wine.

\section{MANURING.}

If the ground be of the description above mentioned, not much will be required in the way of manure unless it be impoverished by some means, such as planting vegetables too near the olive trees. For such as are set out in wheat fields the ordinary cultivation and manuring will suffice, and the same may be said in respect to gardens and orchards. If manure of any kind is to be applied, it ought to be just before the fall of the annual rains. But, under any circumstances, in this climate, there ought to be placed immediately around the plant, or truncheon, a good mat of grass, dead weeds, leaves, or in fact any kind of light rubbish, to prevent evaporation, and to keep the ground cool and damp during the hot weather. In Australia this kind of protection has long been found most beneficial for all sorts of young trees, and is now in universal use.

Having now said nearly all that needs be said about soil, climate, and one or two precautionary matters, we will proceed to describe the methods of raising olive plants.

The first, then, would naturally be by means of the fruit, and that is easily disposed of. It must be borne in mind, however, that it is desirable to crush the berries lightly, so that the juice may soon run away, as it seems to endanger the success of the seed. If the seed (hard kernels) be soaked in lukewarm water for three or four days previous to planting, they are likely to germinate sooner. Large birds, such as turkeys, by eating them and partially digesting the stones, or kernels, have in this way distributed the olive in many countries. The most suitable plan for these countries is to make a seed-bed in a warm, sheltered nook, where the soil is rich and fine, covering it lightly with a loam or fine mold, and over this a pretty fair covering of decaying leaves and small twigs, so as to protect the seed from frost, severe winds, and such vermin as mice. Laid out this way in October or November, they will germinate in April or May. Of course, there will be differences in the time of starting, according to the preparation, or sometimes the kind of seed. In olive countries this method is rarely resorted to; partly because where more than one variety is cultivated in a grove the seed is sure to become hybridized, and because there are other methods more certain of rapidly yielding a return and less expensive. There being in California already abundance of the "Mission" olive, two methods of rapidly rearing the olive grove present themselves. The first is by splitting up the root of an old or useless tree; cut the stem a few inches above the ground, chop the root out of the ground and split it into pieces two or three inches in diameter, and plant these in the places where they are to remain permanently, keep them free from weeds, and otherwise handle them as if they were seedlings. Where a tree can be spared for the purpose, this method is of great use, as, if left to its natural growth and not worked back by pruning, it will yield both fruit, and, what is of more importance, abundance of branches (thick sticks, in fact) which we call "truncheons."

\section{TRUNCHEON PLANTING.}

This method is, by far, the safest, easiest, most economical, and certain to preserve the kind of fruit in purity. It cannot be otherwise, unless it be grafted to other varieties, since it is only the continuation of the parent tree. To this method, then, I wish to invite very especial attention, while I describe the particulars to be observed in order to insure success. And as I have had considerable experience in this way of raising olive trees, and know about the success which has attended it under my own direction, I can speak with perfect confidence. I cannot do so better, I think, than by making an extract from the report which I furnished to the Government of Victoria, Australia :

"Having been intrusted by the commission with the duty of procuring plants of the olive tree, and superintending the planting of them, I have now the honor to report upon the several steps I have taken, and the methods adopted in selecting cuttings and preparing them for planting, as well as the actual process from first to last of placing the plants in situ. Besides planting at the industrial schools ground at Sunbury, where, it is to be hoped, the boys will in future be familiarized with olive cultivation, and a few, as hereinafter mentioned, set out near Sunbury and at Essendon for the purpose of trying a special method of planting in those localities, the principal experiments on a large scale are being carried out at the Acclimatization Society's Gardens, Royal Park, and within easy reach of persons visiting or residing in and near the city. I procured in the first instance one hundred truncheons of at least five feet in length, and from two to three inches in diameter, from South Australia, from olive trees which I saw in bearing in April. 
"These five-foot long truncheons were planted in holes about three feet in diameter, and two feet six inches deep. Some good topsoil and occasionally a little rich loam was placed in the bottom, and on the top of this a handful of perfectly sound barley, such as would germinate as far as it could soon after the planting was completed. Before, however, the truncheon was placed in position the thick end was cut with some sharp instrument, such as a saw, into four or five nicks, about one-third of an inch deep, and these nicks, or saw cuts, were filled with grains of barley thrust carefully into them, for the obvious purpose of supplying plant food as soon as the truncheon might need it. Being prepared in this manner, it was placed firmly upon the barley already placed in the bottom of the hole, and filled up in the usual way, the best soil first, and well trodden about the root end. Great care is taken lest the plant should become loose through shrinkage of the soil, especially the clay. Finally it would have to be watered, had the weather not been very wet, and last of all grass was placed about the stem to keep heat out and moisture in. Distance asunder, forty feet.

"The above comprises the detail of truncheon planting except in one particular. The Italians cut the small end slanting that water may not lodge upon it; but the Portuguese saw it fairly across, and place on the top a little finely tempered clay, as in grafting, and secure it by means of a rag tied over it ; or, better still, paint the top and large knots with shellac, or other such material.

"In this way, as I have said, several hundreds have been already planted at the Royal Park Gardens.

"Considering that it is a primary object with the commission to afford practical evidence of the advantage of one kind of cultivating the olive tree over another, I proceeded to cause several hundreds to be planted of two feet six inches in length, in a way not distantly resembling the one just detailed. They are put out a foot or two asunder in rows, in beds of rich sandy loam, and excellently sheltered from the hot north winds.

"Then I caused another lot, comprising several hundreds, to be planted, of lengths varying from two feet to fifteen inches, in the same soil, but closer together and of varying thickness, say from two and a half inches to half an inch.

"There was only one other way which I have not directed to be tried-that of taking a root and splitting into bits, from the upper part downward, and planting these. It is said this plan never fails. But the difficulty was in this country to find a root of any considerable size; so the idea was abandoned for the present. The advantages of truncheon planting are, that the plant is put once for all in its permanent situation; that it needs little or no care when once it begins to grow; that it bears frequently the second year, nearly always the third, and forms a regular tree, as it should do, not a bush, and secures the identity of a given variety, which cannot be depended upon in seedlings.

"All the other methods necessarily take more time. A year is always lost in the setting of the plants out; and it is rarely under from six to nine years that they come into full bearing, and in this colony especially they are liable to grow into scrubby bushes. I would mention here that I have had a number of truncheons planted in situations most fully exposed to the north winds, and others under the most complete shelter, with a view of affording instruction as to exposure. For hill-side planting Sunbury must answer, for gentle slopes Essendon, while the land at the Royal Park is rather flat.

"The cost of purchase and of planting over one thousand six hundred olive cuttings was about $\$ 225$, or about seven pence each, taken one with another. The commission paid sixpence each for truncheons five feet long.

"Sea air is known to be beneficial to the perfection of the olive; and that we have in perfection. So beneficial is a touch of salt to the tree that in planting in Portugal it is considered advantageous to put down a spadeful of sea sand obtained from near low-water mark."

\section{GATHERING FRUIT.}

In gathering the olives when quite ripe (in October or November in this State), the Portuguese spread tarpaulins, canvas, etc., around the root of the tree, and then thresh off the berries with long light sticks. This seems to do the tree no harm. In South Australia they are generally gathered by children.

\section{CONSUMPTION OF OLIVE OIL.}

During the year ending June 30, 1877 , there were imported into the United States 348,43I gallons of olive oil, valued at \$49I,43 I, on which a duty was paid of $\$ 232,776.75$. The quantity and value of pickled olives imported during the same period are not given in the published Treasury reports, as this article is free from duty.

Of the above, San Francisco imported 47,I92 gallons, valued at $\$ 97$, I I 8 , on which a duty was paid of $\$ 1$ per gallon, or $\$ 47,192$. The 
value of pickled olives imported into San Francisco for the year was $\$ 13,892$.

Great Britain imports annually almost 5,000,oo gallons. Nearly all of this comes directly or indirectly from ports on the Mediterranean, and was produced on land, the rivers and streams of which flow into that sea.

\section{PRUNING OLIVES.}

This process is adequately shown by the subjoined figures. Fig. I shows the young tree to be cut off at C. Six branches, three on each

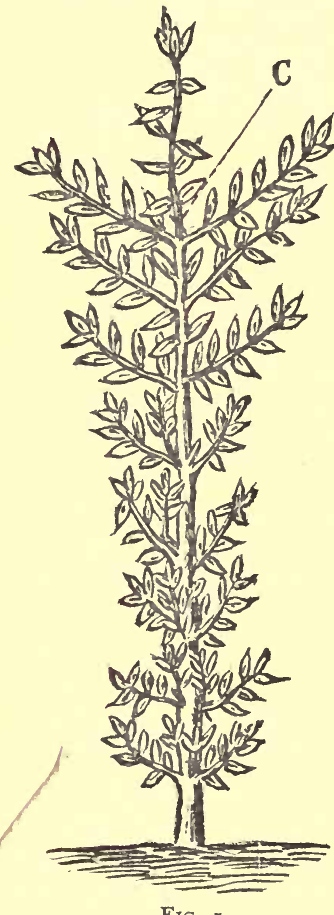

FIG. 1 . side, are left, and the lower twigs shortened. Each branch is developed during the year, as shown in Fig. 2, which is then cut at $\mathrm{C}$ again, and the shoots, $B$ and $D$, are shortened. The upper shoot is started out by this process, and it appears the following year as $\mathrm{A}$ in Fig. 3 , and it is again cut at $\mathrm{C}$. This causes the two upper shoots to develop, and at the end of the year they appear as shown at $\mathrm{B} B$ in Fig. 4. This is their position at the fourth year's pruning, and each of them is cut at $\mathrm{C}$, and $\mathrm{A}$ is shortened, and $D$ is allowed to develop. By this time the tree has a spherical or vase form, and exposes much surface to the sun, which is desirable.

\section{THE HOME OF THE OLIVE.}

While the olive is found wild in a certain climatic zone of the Himalaya Mountains, and is supposed to have been transported in some former age from there to Europe, yet practically all of the olive oil of commerce comes from Italy, Spain, France, Greece, Algeria, Morocco, and other countries which have coasts on the Mediterranean.

Bocardo says that Italy has $1,235,000$ acres planted to the olive, producing annually 30,560 ,oo gallons of oil. Simmons gives the exports in 1854 , of that part of Italy and Sicily then composing the Kingdom of Naples, at 36,333 tons, valued at $\$ 11,263,230$. Nieman gives the

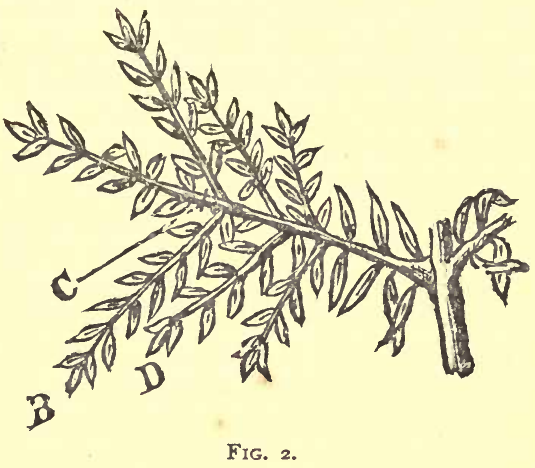

export from Spain for 1873 as valued at $\$ 10$,425,600 . In 1874 , in consequence of the Carlist war, it fell off to $\$ 3,716$,ooo.

France, according to Prudent, produces but a small proportion of the olive oil which it consumes, yet annually exports to the value of $\$ 2$,000,000 .

George P. Marsh, United States Minister to Italy, says "that in the olive, walnut, chestnut, cork-oak, orange, lemon, fig, and other trees, which, by their fruit and other products yield an annual revenue, nature has provided Southern Europe with a partial compensation for the loss of the native forest," and adds: "Some idea of the importance of the olive orchards may be formed from the fact that Sicily alone, an island scarcely exceeding Io,000 square miles in area, of which one-third at least is absolutely barren, has exported to the single port of Marseilles more than 2,000,000 pounds weight of olive oil per year for the last twenty years."

\section{EXPRESSING THE OIL.}

In the south of France, where the most care is given in the preparation of oil for market, the

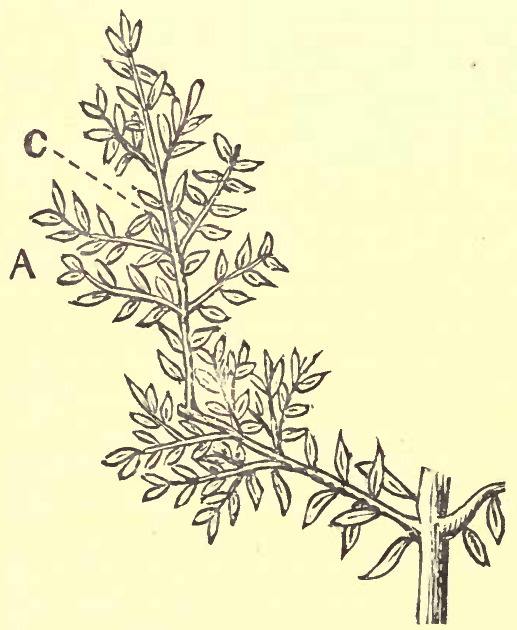

FIG. 3. 
olive ripens in November and December. The fruit is gathered before being fully ripe, but is allowed to remain a few days for the evaporation of any moisture. It is then crushed in an edge-wheel mill of stone, commonly drawn by horse-power. The stone resembles a large grindstone with the edge serrated, and the mill is not unlike the bark mills in use in the United States thirty years since. The object in serrating the edge of the stone is to avoid crushing the seeds or kernels, which contain tannin and a little inferior oil. The virgin oil is dipped from the mill, and is almost invariably kept to enrich poorer qualities of oil. The pomace is placed in coarse linen bags about eighteen inches in diameter. Several of these are put into a screw-press and the power applied. The oil expressed runs into a tank. This gives the first quality of oil. The pomace is now taken from the bags, broken up finely, and again put under the screw-press for a second and third time, on each occasion yielding less oil and of an inferior quality. After the third pressing, the pomace is again broken, and a half gallon of boiling water poured into each bag. It is again pressed, yielding an inferior oil used for burning, lubricating, and in the manufacture of castile soap. Even the virgin oil when first pressed is turbid, but clears itself by standing in vessels not open to the air. It should be kept in places having an even temperature. The product of all of the pressings is about three gallons of oil to the bushel of olives.

\section{PICKLED OLIVES.}

The best olive for pickling is the Picholine (Oleo oblonga). In the south of France it is gathered in October, just before the fruit has commenced to turn brown. The finest are selected and placed in a weak solution of soda, to which lime has been added. After remaining in this solution about ten hours, or until the pulp can be readily detached from the kernel, they are removed and placed in cold water, which is daily changed for a week. The process removes the tannin from the unripe fruit. When they cease to be bitter, they are bottled in brine, which is usually made aromatic with coriander or fennel. The next best variety for pickling, is the Olea minor lucensis, ninth variety in New Duhamel. This is also valuable for oil.

In Portugal the ordinary larger kind grown for oil is used to a vast extent as food, and the experience of ages in that country, and of the

whole Hebrew race (the healthiest race of men in the world), everywhere bears testimony to its value. If he had to go one hundred miles for his olives, the Jew would have them.

Without attempting to give the details of treating the Spanish olive for long preservation, for export, etc., I may in this place mention that the olive plays no inconsiderable part in the ordinary food of the people of Portugal; and the experience of ages has shown it to be both grateful to the palate and wholesome. Now the common practice is to allow the larger and more fleshy kinds to become ripe, i. e., black, when they lose a good deal of their astringent and acrid taste. These are then scalded in water considerably under boiling, into which an ounce or so of soda to the gallon is dissolved, and let stand in it for three or four hours-in fact, till it is cold. They are then taken out and well washed in cold water several times over, and finally put into a clean wooden or large earthenware vessel, and completely covered with a pretty strong brine of salt and water, and covered up from the air. Another lot, first treated as above, is put down as a pickle in moderately strong vinegar and used as required.

When I allude to the preparation of Spanish olives for export, I only mean the plans adopted in packing, in pickle, oil, bottling, etc. The preparation of the fruit is alike in all casessave that when dealing with the full ripe ones we remove the salt-water pickle three or four. times at intervals of a week or so, and each time the berries are rendered more mellow. I have kept them in ordinary large earthenware 
jars, merely covered by the lid, for more than two years, in. Melbourne, without appearing to change for the worse.

When engaged in the duties of the Royal Commission for Foreign Industries and Forests in Victoria during 1870-I, I endeavored to obtain as much information as I could from botanists, and from gentlemen experienced in the growth of the tree in Australia, for such practical knowledge is often preferable in new countries to aught that can be obtained from books. Accordingly, I obtained the following from my illustrious friend, the Government Botanist :

\section{NOTES FROM BARON VON MUELLER.}

"For grafting seedling olives there are at the Botanic Gardens, Melbourne, four renowned varieties, obtained from the Honorable Samuel Davenport, of Adelaide, who, for a series of years, has given much attention to this branch of cultural industry, studied this with other rural questions during a stay in South Europe, and wrote last year an instructive little publication on the cultivation of the olive. These varieties are :

"(I.) Verdale-Available for a good table oil, as well as for green conserve. This and the next following are early and abundant bearers.

"(2.) Blanquet - Adapted for dry ground. The oil is of a particularly sweet, delicate taste, and more pale than other kinds, but does not keep so long. This and the Verdale produce the fruit on low-growing branches, so as to be accessible for hand-picking.

"(3.) Bouquettier-For superior oil.

“(4.) Redounaou - Eligible for colder regions; produces table oil, and is also esteemed for conserves.

"Some other kinds are locally available, among them the Olivier de Grasse, the latter yielding an excellent table oil and oil for perfumery, but the plant is high of growth, and the gathering of the fruit more expensive. It is of a weeping habit. Baron Von Mueller has also entered into arrangements with correspondents in various parts of South Europe to obtain other superior varieties which as yet are not introduced into Australia. The American system of establishing at regular distances lines of shelter plantations of trees on farm land, might be adopted for planting olives. In such cases quick-growing timber trees may be chosen in the first instance along with the olives to pro. vide shelter earlier than otherwise possible.

"Whenever olive fruits cannot well be locally utilized, they should not be allowed to go to waste, but be sown with a view of obtaining a copious stock of seedlings, to be grafted, a proviso which is easily accomplished a very few years later. Seedlings under the cover of decaying foliage spring up spontaneously in masses from dropped fruits.

"The planting of olives cannot be sufficiently impressed on proprietors of arable soil, the climate of most parts of Victoria having proved singularly well adapted for richly productive olive culture, as in a multitude of places near Melbourne and elsewhere may be seen. While a gold-field becomes exhausted, an olive plantation increases in value for a long series of years, and becomes a lasting source of revenue to its possessor. The yield is annually at once salable, while it is for many small farmers more readily remunerative than grapes, if the latter are to be converted into wine. The olive, moreover, is a hardy plant, and hardly subject to any diseases which might render the yield precarious. The processes of gathering the fruit and preserving the oil are of the simplest kind, and do, therefore, not necessitate the application of skilled labor.

"Mr. Davenport's management of truncheons is to bury them horizontally in the ground about four inches below the surface, in a good vegetable mold, neither subject to dryness nor too much moisture. After two years the young trees, then three to five feet high, are transplanted to permanent positions, the month of May being the time chosen for the purpose. Olive oil produced in Adelaide this year was sold at twelve shillings the gallon to grocery establishments, the fruit being mostly from seedling trees. Careful hand-picking costs in Adelaide four pence per bucket. The work gives good employment to children, who manage to pick six buckets a day, and, if experienced, may gather more. Any simple structure will answer the purpose of pressing, coir matting bags being used for the crushed olives for successive piles under the press. The first oil obtained by gentle pressure is the best. It is not at all unlikely that the olive plant would thrive in many parts of the salt-bush country on the Murray River, now not utilized for any cultural purposes."

Mr. Thomas Hardy, of Bankside, near Adelaide, South Australia, writes :

"My knowledge of the olive is very limited; the oldest trees I have were planted in 1858 , and have borne fruit five years. They were planted as seedlings of one year's growth, and have never been grafted. I have never tried growing them from truncheons, but I know that Mr. Samuel Davenport has succeeded in grow- 
ing them in moist ground from cuttings fifteen to eighteen inches long, and from one-half to one inch through. They are planted very sloping in the ground, with a very small portion left above. These mostly root enough in one year to remove the next for planting out. I have also seen large limbs of old trees planted partly in the ground, and a mound of earth three or four feet high piled up round above the surface, but they did not do well; the climate here is too dry in the summer. The favorite way seems to be to plant seedlings, which are very abundant, and can be bought for about $£ \mathrm{r}$ per one thousand. These are large enough to graft in two years, and can be planted out the following season with a pretty sure prospect of success. I am not/ acquainted with the different kinds of olives grown here, Mine are all seedlings, and produce pretty fair sized fruit, but I find I have two or three trees very much superior to the rest, and shall graft them all to those kinds if I find I can succeed by grafting in the larger branches, which I shall try this season. My olives bear more abundantly every second year, and I do not see that the hot winds have any bad effect on them; I never find the fruit drop off after them, like oranges do. I managed to keep my olives three years by spreading them on the trays I use for fruit drying. I had them all crushed at the goal by the prisoners, and the oil from the dried berries was considered quite equal to that got from fresh fruit. I have no knowledge of the produce per tree of mine, but a friend, Mr. Quick, of Marden, last year made two gallons of fine oil from a tree in his garden; he has promised to give me the age of the tree, etc., and if I get it I will inclose it. I notice that the olive grows well here in all soils, even in salty land that will not grow any fruit tree. I have my olives gathered by children, and pay them two shillings per hundred-weight for gathering; they earn about one shilling per day. I do not let them beat the trees, but let them get up and shake the branches, or stand on the ground with a long light pole with a crook fixed at the end to seize hold of the branches; the crook is made of iron of a particular shape, and is covered with soft stuff to prevent it barking the branches. The trees have to be gone over several times, as the olives do not all come off with the first shaking. The olive should not be planted less than twenty feet apart, and that will be too close on good land."

The following is from my correspondent, $\mathrm{Mr}$. P. A. Gugeri, now of Western Australia, where he is now engaged in cultivating olive trees and vines:
"The olive is a tree that ought to be cultivated wherever it will grow. The labor of gathering the olives is not so much as some think. If the trees are so pruned as not to grow above fourteen or sixteen feet high, the olives are easily beaten off the trees with long sticks, large cloths or tarpaulins having been spread under the trees to receive the berries. A man could easily knock down five hundredweight a day, which would make nearly four gallons - at least, three and a half-of oil.

"The process of oil-making is very simple in expressing the oil. It can be done with a hydraulic, or any large screw-press, the olives being placed in a perforated cylinder and pressed. Oil and water will come over. This should be received in a tub, the oil rising to the top in half an hour or so, when it is skimmed off and put into a cask, or other convenient wooden or earthen vessel, and let stand where the light cannot reach it to clear itself. Great care should be taken to skim off all the oil before fermentation of the fruity juice of the olive sets in, or it will be re-absorbed and lost. .We consider this the very finest oil.

"The stones that remain at the end of this process may then be ground under a heavy stone, such as a millstone, to pulp, mixed with hot water, placed in a strong bag of canvas, or like material, and pressed as before."

As to the best time for gathering the fruit, it seems to be just when it approaches natural ripeness; but about Lisbon they were left on the trees till fully ripe.

Pliny condemned the practice of leaving the fruit over long on the trees, as he considered that by so doing the next year's crop is injured. "Hærendo, enim, ultra suum tempus absumunt venientibus alımentuın."

The following is from the paper of B. B. Redding, Esq., already mentioned, and well deserves to be recorded here. My warmest thanks are due, and tendered, to him for his kindness and urbanity in allowing me to use his labors.

\section{INTRODUCTION OF THE OLIVE INTO CALI- FORNIA.}

"I have found it very difficult to obtain the history of the introduction of the Mission olive into California. It was first brought to America by Antonia Ribora, who took it from Spain to Lima in 1560. Frezier speaks of the olive being used for oil in Chile as early as 1700 . Frank A. Kimball, of San Diego, in an article on the olive in the Southern California Horticulturist, states that the first olive trees were planted by the Spanish missionaries at that 
place in 1769 . If this is correct, they are from seed forwarded from San Blas in Mexico by Don Joseph de Galvez, who fitted out an expedition by virtue of a royal order to 're-discover and people the port of Monterey, or at least San Diego,' which expedition accompanied Father Junipero Sera in his missionary efforts 'to extend the spiritual conquest of the North.' Fifty years later it is recorded 'that all the seeds that Galvez had been so provident in sending up took root and prospered. The fathers built new missions, and continually replenished their stock of converts, which, at one time, were about twenty thousand. They planted vineyards, orchards, and the olive.' From San Diego the tree was transplanted to nearly all the other missions, and from these missions to various places throughout the State. Other than those at San Diego, Santa Barbara, and San Luis Obispo, I cannot learn that this tree has as yet been planted in orchard form, with the object of making profit from its fruit.

\section{THE MISSION OLIVE.}

"H. N. Bolander, who had charge of the botany of the geological survey of the State, informs me that in all of the missions there was but one variety of the olive, one of pear, and one of grape.

"I have made considerable effort to learn the name of this particular olive, and to ascertain if this variety is cultivated in Europe, but without success. John Ellis, who has charge of the horticultural grounds at the University, informs me that the seeds of the Mission olive 'come correct, and produce fruit of the same kind as the parent.' From the fact that the seeds produce trees bearing the same kind of fruit as the parent, it would be safe to conclude that it is the original stock of the wild olive of Europe or Africa. It is a shy bearer, and has fruit very much smaller than the varieties cultivated in Italy and the south of France. It is probably very valuable as a stock on which to graft or bud more prolific kinds. It has, however, demonstrated that the best varieties can be successfully grown over a wide range in California.

\section{A USEFUL AND PROFITABLE TREE.}

"I can find no other tree so useful and profitable that will grow and thrive with so small an amount of moisture. If, as many believe, the annual rain -fall of a given place can be increased by the planting of trees, I do not know so useful a tree to recommend for this purpose.

$f$ it should fail in adding to the rain, it will be certain to thrive on what rain does fall, and be sure to yield oil whether cultivated or neglected; for what Virgil wrote nineteen hundred years ago is still true. After having described the continuous culture necessary for the vine, he adds: 'On the other hand, the olives require no culture, nor do they expect the crooked pruninghook and tenacious harrow, when once they are rooted in the ground and have stood the blasts. Earth of herself supplies the plants with moisture when opened by the hooked tooth of the drag, and weighty fruits when opened by the share. Nurture for thyself, with this, the fat and peace delighting olive.'"

The following is from a most ably written and interesting article by Augustus L. Hillhous, in Michaux's North American Sylva, vol. ii, pp. I 30 et seq.:

"The olive has been called the polypus of trees, for it is propagated by all the known methods of propagating trees-by sowing the seed, by layers, by slips, by cuttings of the root, by sprouts separated from the trunk, or from roots of the parent stock. Seed planting is generally rejected on account of the length of time before bearing. When it is resorted to the best sorts only are selected, of these the Gros Ribés being considered the best. The pulp is removed and the berries cleaned in an alkaline solution, and planted, in March, in well manured, rich, deep soil, in a sheltered locality, two or three inches deep in trenches." [For convenience of removing, the seeds should be six inches asunder, unless "thinning out" be contemplated.] "To accelerate the germination, the stones may be kept in fine mold during the summer and autumn, and sown in the beginning of January. They soon germinate, and are strong enough to bear removal the next winter. These will have to be grafted, and the best method is by inoculation, and the safest time for it is the close of winter or the opening of spring."

\section{OIL MILL, AND THE WORKING OF IT.}

The oil mill retains nearly its primitive form. It consists of a basin raised two feet from the ground, with an upright beam in the middle, around which a massive millstone is turned by water, or by a beast of burden. The press is solidly constructed of wood, or of cast-iron, and is moved by a compound lever. The berries, after being crushed to a paste, are put into sacks of coarse linen, or of feather grass, and submitted to the press.

The virgin oil, which is the first discharged, is the purest, and retains most sensibly the taste of the fruit. It is received in vessels half 
filled with water, from which it is taken off and set apart in earthenware jars. To separate any vegetable fibers and other impurities, it is frequently decanted. When no more flows, the paste is broken up, treated with hot water, and pressed again. This is often done a third time. The best oil for domestic purposes is made from the pulp only. A machine has been made for pulping without smashing the stones, which contain a little tannic acid. All the inferior qualities find their uses in machinery, in soapmaking, lamps, etc.

Two things occur to me to mention in this connection, viz:

(I.) If the crushed matter be allowed to stand for any considerable time-say three or four hours-fermentation will have set in if the oil cellar be warm, and the loss of oil will be quite considerable.

(2.) Wherever the oil cellar is situated and the various operations of purifying are conducted, direct sunlight must be excluded if the oil is to remain good. It must never for one minute see sunlight, or it is spoiled.

A list of seven favorite kinds, from a note in Michaux :

(I.) Olivier Pleureur-Fourteenth variety of the New Duhamel; a fine tree, somewhat resembling a weeping willow; good both for table and oil; Mr. Thomas Hardy, of Bankside, South Australia, has it.

(2.) Olivier á fruit arrondè (Olea spherica) -It requires moisture, good soil, and plenty of manure. Good for oil.

(3.) Olivier de Lucque (Olea minor lucensis) - Hardy, and yields fruit for preserving.

(4 and 5.) Aglandeon-Are good for oil, and prefer dry and elevated grounds.

(6.) Olivier Amygdalin-Much prized about Montpelier for its fine and abundant oil.

(7.) Picholin (Olea oblonga)-Yields the most celebrated pickled olives. This variety is not delicate in its choice of soil and climate.

The following extracts from Busby's fournal are both interesting and useful :

"About a mile from the town we struck off into a plantation of olives. Few of the trees, however, contained any considerable quantity, and some were altogether without fruit. Such olives we pulled were universally rotten. I was afterward told by Mr. Gordon that all olives are rotten this year, and that this is invariably the case every second year. A little farther we saw a new plantation on the opposite side of the road, and luckily found a peasant. To our questions respecting the olives, he informed us that the plants bear a little fruit even the first year; but, in the second and third years, they bear a considerable crop in proportion to their size. Some of what we saw had been eighteen months, some only six months. The former appeared healthy young trees, covered with a considerable quantity of foliage. The latter had only a few slender shoots, and some of them indeed stood in their original nakedness. The olive plants were nothing else than large limbs of old trees from eight to ten feet in length and from two to three inches in diameter. They are sunk about four or five feet in the ground, and the part of the plant above ground is covered, during the first summer, with a cone of earth or clay to the hight of from two to three feet.

"The olive having been mentioned, we were shown two trees which supported a wheel for drawing water from the well. Two posts having been required for this purpose when they were clearing the ground of some olive trees three years ago, they took two of the trunks of these, which were respectively ten or twelve inches in diameter; they nevertheless took root, and are now covered with strong branches, affording a proof of the great facility with which the olive takes root. The vinador said that an olive would produce a crop three years after its plantation, but not a full crop till its fifth year, and would reach its greatest perfection in its tenth year. He said a plant ought to be the limb of a tree of the thickness of a man's arm. Being asked how long it would take before a slip such as we plant in New South Wales would bear a crop, he appeared to consider the proposal as ridiculous, and said he thought twenty years. He did not consider the oil of young olives inferior to that of the old; the only difference in their value arises from their quantity. The trees are planted with considerable regularity, at the distance of thirty-six or forty feet. An average crop is from one and a quarter to one and a half arrobas-that is from five to six English gallons each tree.

"When rain falls in August, the olives always suffer from it. All the ground we saw was a light sandy loam. It is plowed once a year. They plow an aranzada of the olive ground in a day, but not more than half that quantity of the meadow or corn land below. There are five kinds of olives on the estate; one of them, the 'La Reyna,' is of a very large size, and is pickled for eating. The tree of this variety produces but little fruit, and the fruit when pressed yields very little oil, but is highly prized for eating, being as large as a good sized plum.

"After having been brought home, the olives lie in a heap on an average about fifteen days 
before they are crushed. After having been crushed, they are put into the press, and it is the common practice to pour hot water upon them in order to extract the oil. They are pressed thrice, and each time with addition of boiling water. The fluid runs from the press to a cistern, and when it is filled, the oil flows over the top, leaving the water below, which is cleared away as necessary. The peasant said that all the difference between the fine and common oil was, that the former was the virgin juice drawn off with cold water, and not mixed with the second and third pressings. The trees on this property are reckoned very young for olives, although they are sixty years old. They are pruned every year. But olive trees are said not to require pruning at all till they are twenty-five or thirty years old. Two hundred aranzadas are equal to one hundred and ninety-one English acres; and three thousand arrobas of oil (the average annual produce) are equal to twelve thousand seven hundred and thirty-five English gallons, old measure-about sixty-three and three-quarter gallons per English acre. I do not know, however, whether there was not included in this estimate forty aranzadas that are entirely planted with the 'La Reyna,' which are never pressed for oil. Even with this deduction the produce would fall very far short of what the trees of the Hieronomites were said to produce, viz: from three to four fanegas of olives each tree, each fanega yielding an arroba of oil. An English acre will contain sixty trees twenty-seven feet apart, and sixty was said by the peasant to be the number on each aran$z a d a$. One hundred and fifty-three acres, bearing sixty trees each, will contain nine thousand one hundred and eighty trees, and the produce being three thousand arrobas, it is scarcely onethird of an arroba for each tree. This comes nearer to Don Jacobo Gordon's statement, that from one and a quarter to one and a half arroba is reckoned a good return from each tree. The trees of the Hieronomites, as well, indeed, as the most of those I saw in the neighborhood of Xeres, were planted on a richer soil, and were of much larger dimensions; but this could never cause such a difference as to reconcile the different statements."

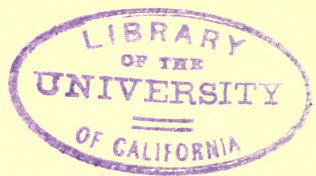






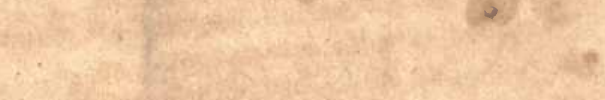

\section{UNIVERSITY}

OF CALIFORNIA

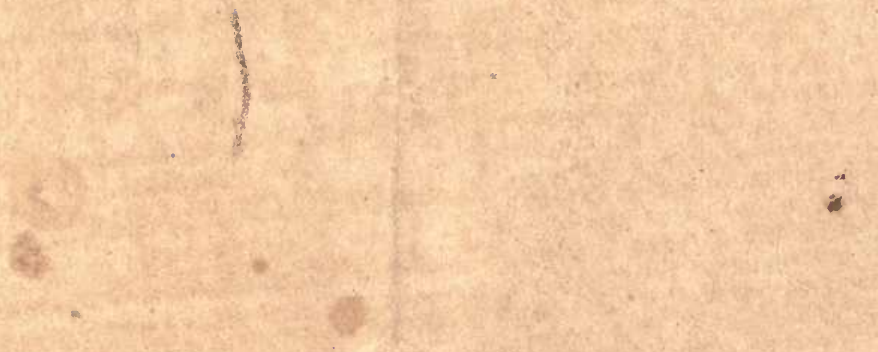






